Int. J. Electrochem. Sci., 11 (2016) $6819-6829$

International Journal of

ELECTROCHEMICAL

SCIENCE

www.electrochemsci.org

\title{
Corrosion Inhibition Action of Sulfamethoxazole for Brass in Acidic Media
}

\author{
Tambi Ramdé $e^{1,2, *}$, Stefano Rossi ${ }^{2}$, Lucien Bonou ${ }^{1}$ \\ ${ }^{1}$ Equipe Chimie Physique et Electrochimie, Laboratoire de Chimie Moléculaire et des Matériaux, \\ Université de Ouaga I Pr Joseph KI-ZERBO, \\ 03 BP 7021 Ouagadougou 03, Burkina Faso. \\ ${ }^{2}$ Department of Industrial Engineering, University of Trento, via Sommarive 9, 38123 Trento, Italy \\ *E-mail: tr_ramde@univ-ouaga.bf, ramde.tmb@gmail.com
}

doi: $10.20964 / 2016.08 .39$

Received: 1 May 2016 / Accepted: 8 June 2016 / Published: 7 July 2016

The corrosion inhibition action of sulfamethoxazole (SMX) on aesthetical brass has been investigated in synthetic acidic rainwater by means of potentiodynamic polarization, electrochemical impedance spectroscopy (EIS), optical microscopy, scanning electron microcopy (SEM) and Fourier Transformed Infrared spectroscopy (FT-IR). It was found that SMX inhibits the corrosion of the brass and the inhibition efficiency increased with increasing concentration. Maximum inhibition efficiency of about $84 \%$ has been obtained at the higher concentration of SMX in the synthetic acidic rainwater. Long time immersion test showed that the inhibition efficiency increases with immersion time as indicated the increase of total impedance. Surface characterization performed by FT-IR, optical and SEM analyzes allowed to establish that SMX acts as inhibitor by forming protective adsorbed layer.

Keywords: brass, sulfamethoxazole, corrosion inhibition, electrochemical impedance spectroscopy

\section{FULLTEXT}

(C) 2016 The Authors. Published by ESG (www.electrochemsci.org). This article is an open access article distributed under the terms and conditions of the Creative Commons Attribution license (http://creativecommons.org/licenses/by/4.0/). 